\title{
Maslaha as the Philosophical, Political, and Legal Basis on the Islamic Banking Legislation in Indonesia
}

\author{
Abdul Ghofur (Corresponding Author) \\ Walisongo State University of Islamic Studies, Semarang, Indonesia \\ Walisongo Street No. 3-5, Semarang, Central Java, Indonesia \\ Tel/Fax:- +6224-7604554 / +6224-7601293 E-mail: aghofur2009@gmail.com \\ Sulistiyono Susilo \\ J1.Prof.H.Soedarto, S.H.Tembalang, Tembalang, Kota Semarang, \\ Central Java, 50275, Indonesia \\ Tel:- +62 247460012 E-mail: sulistiyonosusilo@gmail.com
}

\begin{abstract}
Legislation on the Islamic Banking Acts in Indonesia is inseparable from the condition of national politics and global economics that continues to develop. In this paper, the main issue to be discussed is whether the formation of the Islamic Banking Act in Indonesia is based on political interests, or if there is also a legal value associated with economic development of this act. The findings suggest that the legislation on the Islamic Banking Act in Indonesia has relevance to the political and legal foundation that developed at that time; and the legislation on the Islamic Banking Act is based not only on the political but also the philosophical aspects of law that emphasize principles of the common good or mașlaha and/ an alignment with national goals.
\end{abstract}

Keywords: Islamic Banking Act; Politics of law; Legislation; Philosophy of mașlaha; Indonesia

\section{Introduction}

Mașlaha or mașlaha al- 'amma as one of the commonly used approaches in ijtiha d, is the goal to be realized by the Islamic law (shari 'a) application. It is the essence of the policies implemented to realize the common good (alsiyāsa al-shar '`yya) in response to the social, political, and economic challenges (Opwis,
2005), and plays a vital role in the development of Islamic economics and economic policy (al-siyāsa al-iqtișādiya) (Dusuki \& Abdullah, 2007; Mansour, 2014). Mașlaha is a cornerstone of Islamic rules on transactions (mu'àmala), which is the benefit framed with shari 'a and not solely based on profit motive and material rentability as in conventional economy (Dusuki, \& Bouheraoua, 2011).

Mașlaha in the recently geographical, social, political, and cultural contexts will bring different nuances of interpretation, scope, language, and idioms though essentially they have virtually the same and universal meaning. The development of Islamic economics in the face of changes and the rapid progress of science and technology must be based on the mașlaha. Muslim scholars state that where there is maslaha, there is shari' $a$ of God. This means that in everything containing mașlaha, there lies the sharì' $a$ of God. Thus, mașlaha is the most important concept in Islamic law.

To discuss the masslaha in the contemporarily practical instead of theoritical term, this study focuses on legislation on the Islamic Banking Act in Indonesia which has a strategic role in providing a foundation for the ongoing activities of Islamic banking, which so far does not have a legal basis that specifically regulates it. The bank has developed rapidly at the regional, national, and global levels. In 2007, Islamic 
banking assets worldwide reached US\$500 billion. According to the World Islamic Banking Competitiveness Report 2011-2012, those assets have increased to US\$1.13 trillion as of 2012. The Islamic Bank has expanded in not only Muslim countries, but also in European countries, the United States, Singapore, Hong Kong, and China. Islamic banking at the global level includes theWellington Management Company (USA), Oasis International Equity Fund of Flemings Bank (UK), the Hong Kong Shanghai Banking Corp. (HSBC-London), and ANZ Bank (Melbourne, Australia).

Islamic Banking is a leader in the Islamic finance industry, and with the enactment of Act No. 21 of 2008, Islamic banking in Indonesia has become stronger. The legislation is regarded to realize the benefit at the level of political practice. This is justified by the discourse of Islamic jurisprudence (fiq $h$ ) recognizing a term al-siyāsa al-shar' 'iyya, in which the ruler (imām) may determine a particular policy to enforce such goodness though the policy may not have been explicitly mentioned by the sacred texts. Theoritically, Islam has been demonstrated relevant to the needs and interests of humankind over time and geographical context. Laws, in fact, become dependent and are highly affected by power and certain political conditions. This theory recognizes the political struggle that exists when the act is formed and the base used as a benchmark in the determining act. In the context of Act No. 21 of 2008, these two issues of the political struggle and the act of determination are intertwined (Mahfud, 2010: 4). In reality, established laws or legislations are essentially a crystallization of various political interests. Hence, this study discusses the aspect of maslaha in the philosophical, political, and legal basis of the Act by considering the legislation on the Islamic Banking Act in Indonesia that deals with the theory of politics of law, that can be regarded as modern political practice of al-siyāsa al-shar' ’̀yya.

\section{The Concept of Maṣlaha in Islam}

The basic principle of Islam in the political practice of establishing public life at the local and national levels (siyāsa al-dunya) is to meet the needs and welfare of the people (Khallaf, 1977). Mașlaha is the ultimate goal of Islamic law and becomes its main core. In general this is known as al-mașlaha al- 'amma, the substantive and universal goal of the implementation of the sharí' $a$. In general, mașlaha is understood as goodness, benefit, human welfare and prosperity in the world and the hereafter, and the prevention of harm (Griffith-Jones, 2013). According to al-Shātibī (1341 AH /1922), the benefit is primarily intended to guarantee basic human rights, which include freedom of religion (hifz al-dīn), physical and mental protection (hifz al-nafs), family and descendant protection (hifz al-nasl), property or property rights protection (hifz al-māl), and intellectual protection or freedom of thought (hifz al-'aql) (Opwis, 2005).

In the history of Islamic law, al-mașlaha al-mursala, meaning for the public interest, which was simply later called al-mașlaha, is known as one of the products of ijtihäd through human reasoning $\left(r a^{\prime} y\right)$. Islamic scholars tend to understand it as a legal theory. The Islamic jurist who has successfully developed the theory is Imām Mālik ibn Anas (93-179 $\mathrm{AH} / 711-795 \mathrm{CE}$ ), who is famous as the founder of the school of Māliki. According to Imām Mālik, public interest or goodness is one of the sources of the shari' $a$. This is governed by three conditions. First, the public interest is not of things related to worship ('ibādah) (Ahmed, 2006). Second, it should be in harmony with the spirit of the shari' $a$ and not in conflict with one of the shari' $a$ sources. Third, it must be something that is essential and indispensable, rather than something meant for luxury. Indispensabilitythings are a matter related to indespensible things the five objectives of Islamic law (Mahmassani, 1961). 
Al-mașlaha occupies a very significant position in determining the details of the general principles of laws and constitutions in Islam. For example, the Qur'ān and hadīth (the Prophet's sayings and deeds) do not specify what form of government a state, neither monarchy nor democracy might have because the essence lies not in the form of government, but the general principles that have been outlined in the Qur'ān and hadith (Khan, 2006). Therefore, through al-mașlaha, men and women are given the authority and freedom to choose their own form of government and determine what is best for them (Shah, 2006). Perhaps, a monarchywhich is consequently capable of implementing the general principles of Islamic law as outlined in the Qur' ān and hadīth — will be better than a democratic form of government that ignores the general principles of Islamic law. Similarly, it may happen in the opposite way (Khan, 2006).

Therefore, it is not surprising when Ibn Taymiyya (661-728 AH/1263-1328 CE), one of the pioneer Islamic reformers, in his theory focused more on the role of shari' $a$ in the state than the caliphate (the Muslims leadership as the state system). He proposes that any form of Islamic government is nothing but an instrument of shar' 'a. Thus, he emphasized more on the supremacy of Islamic law than on the rigid form of the state. Ibn Taymiyya's arguments cannot be separated from the theory of mașlaha in Islamic law, which enables alternatives of political institutions that will be used by humans in accordance with the needs and the development of society (Black, 2011; Afsaruddin, 2011). This condition comes with the provision that such political institutions or forms of government, which have been determined, can ensure the validity of sharì' $a$ in the country.

Thus, we can conclude that al-mașlaha is very useful in society. Through this principle, the men and women can manage all aspects of social life that have not been regulated in the Qur'ān and hadith. The universal and basic principles of the Qur' ān can be elaborated further in order to determine its application in the national and social life so far as it is not contrary to the spirit of Islamic law. In essence, it is the people or society themselves who know how al-mașlaha relates to their circumstances. Therefore, as free, dignified, and sovereign creatures, humans were given authority to regulate their own affairs in accordance with the public interests.

\section{The Political Basis of Legislation of the Islamic Banking Act}

Islamic Banking in Indonesia is an interesting phenomenon to observe, especially since the formation of Act No. 21 in 2008. This Act specifically is linked to the validity of Islamic law in Indonesia. Historically, the enactment of Islamic laws in Indonesia has created both positive and negative relationships with the political situation that developed in each era (Jaspan, 1965). At the time of Dutch colonization, for example, there were theorie receptio in complexu and theorie receptie. The theory of receptio in complexu was proposed by Prof. Mr. Lodewijk Wilem Christian van den Berg (1845-1927). This theory stated that for Muslims who lived in the Dutch East Indies territory was fully applicable Islamic law because they had embraced Islam. This theory was a fairly tolerant view of the colonial government regarding the application of Islamic law by the Muslim community. However, in the next period, this theory was opposed and replaced by receptie theorie, proposed by Cornelis van Vollenhoven (1874-1933) and Snouck Hurgronje (1857-1936), the orientalists and advisers on indigenous affairs for the Dutch East Indies colonial government. This theory stated that Islamic law would be applied only if it was desired or accepted by customary law (Suny, 2017; Tobroni, 2009). Shortly, according to this theory, the position of Islamic law was under customary law.

Before and during the early years following independence, there appeared receptie exit theory and receptio in contrario theory (Feener, 2007; Thalib, 1980). The theory of receptie exit was stated by Prof. Dr. Hazairin Harahap 
(1906-1975), a prominent scholar of Islam law and Indonesian customary law. The emergence of this theory departed from Hazairin's concern that Hurgronje's theorie receptie attempted to marginalize Islamic law by countering it with customary law to divide the Indonesian society (Tobroni, 2009). In essence, the theory of receptio exit seeks to restore the position of Islamic law as a partner of customary law. Furthermore, this theory was elaborated in more detail in receptio in contrario theory proposed by Sayuti Thalib, a disciple of Hazairin. This theory reaffirmed that Muslims apply Islamic law. Customary law may apply if it is not contrary to Islamic law. In this context, the position of Islamic law lies above customary law (Thalib, 1980).

In the early days of independence, the relationship between Islam and the state was marked by the elimination of seven words from the Jakarta Charter, stipulating that Muslims should implement Islamic law (Lindsey, 2008). During the Soekarno regime (1945-1966), the position of Islam was only a complement to Soekarno's efforts to incorporate various elements of the nationalist and communist forces. At this time, various rebellions were perpetrated by Muslims in various provinces to counter Sukarno's political authoritarianism (Hadiz, 2011).

Later in the regime of New Order Era (19661998), there was a long-standing struggle of ideology in order to recognize Islamic laws (Ali \& Effendy,1986; Thaba \& Gaffar,1994). During the period, the dynamics of the relationship between Islam and the government shifted chronologically with three different relationship characteristics, and they are the antagonistic relationship (1966-1981), the reciprocal and critical relationship (1982-1985), and the accommodating relationship (1986-1998) (Ramage, 1997; Salam, 2016). The policies adopted by the New Order regime included the policy of domestication and accommodation of Islam. Since 1998 (also known as the democracy era), the government has provided freedom for differing parties to express desires, including efforts to formalize various Islamic laws.

The politics of law is an official guideline used as the basis of departure to create and implement the law in order to achieve national goals (Mahfud, 2010: 15). It can also be said that the politics of law is an effort to make the law more of a process to achieve the stated goals. In this sense, the main purpose of the national politics of law is to have the national goals serve as a foundation for the national legal system that should be built with content choices and ascribed processes. Legislation, as an important form of politics of law, is an important pillar of the national politics of law in order to realize the holistic and comprehensive national legal system (Rosadi \& Desmond, 2012).

From a legal agenda standpoint, the politics of law is aligned along a common goal. The law must be present in its essential form as the law, namely: ensuring a fair arrangement, providing legal certainty, and distributing benefits. This is what distinguishes the politics of law from other political concerns (e.g., the politics of economics, culture, and so forth). The ideal values inherent in the law (justice, certainty, and usefulness) are the basis and starting point of the politics of law. Because the raison d'etre of law is to serve the public interest, all elements of the law-such as fairness, certainty, and usefulness - are a common instrument to serve volonte generale or the common interest. Herein lies the ideal properties inherent in legal politics. The primary mission of the politics of law is to provide a foundation for the common devotion and interests.

There are at least three legal positions in the politics of law. First, the law is an instrument, or a tool used to realize the goal, therefore, its quality and capabilities must be ensured. Second, it is the mission carrier and the medium that holds all the desires and aspirations of the various things we want to organize and accomplish. In a mission to improve the situation and objectives, the law is equipped with coercive 
power supported by the legitimate authority and clearly regulated, so that its effectiveness is guaranteed. Third, it is a tool of management that organizes all interests fairly, regulates what to do and what not to do, manages the rights and responsibilities of individuals, groups of institutions, sets up the sanctions, and is equipped with the law enforcement apparatus (Tanya, 2011: 9-10).

In such a position, the law has the potential capability to carry the mission of achieving the objectives to be realized. It is a public resource with the underpinnings necessary for the purposes of achieving the goal. The law has a legal basis - a legitimate basis as created by the representative institution, and it is a connective force, with its sanctions enforced by legal institutions. That is the central position of the politics of law. In the context of the politics of law, the law is a tool that works in the legal system in order to achieve national goals or ideals of the Indonesian society. The law has philosophical power if the legal norms are in accordance with rechtsidee (the ideals of the law) as the highest positive value. In line with the national development objectives in Indonesia to achieve the creation of a just and prosperous society based on economic democracy, economic systems must be developed to support the realization of the development objectives. The presence of an Islamic banking institution is supposed to be an alternative means to achieve that goal (Dogarawa, 2012; Ghoul, 2011).

The existence of the law is not an ends, but merely a bridge that will lead us to desired ideas and ultimately results. Therefore, it should be clear what type of society is aspired by Indonesians. Having in mind the community aspired by the Indonesian people, then we can decide what type of legal system is needed to lead us to a desired society, and what type of politics of law can create the desired national legal system (Hartono, 1991).

\section{The Legal Basis of Legislation on the Islamic Banking Act}

The formation of Act No. 21 of 2008 concerning Islamic Banking has basically refuted arguments of some circles stating that the formalization of Islamic law be considered a positive law is not necessary. This can be seen from the fact that Islamic banking institutions have successfully developed in the context of the rule of law and that the institutions could never survive without the legal basis that supports their existence. The existence of Islamic banking institutions has taken its root from the common practice in society, and tends to develop in accordance with the time.

This Act formation becomes increasingly important because it will be one of the legal bases for all elements of the state, especially those related to banking activities. Therefore, no one, including government officials, should be able to take action without following a foundation of law. In a democratic country, regulations are made by people through their representatives in the legislature in accordance with their will and aspirations. Through this legislature, their interests are aggregated and then incorporated into legislation. Later, the regulations are binding and must be obeyed by all people. For that reason, regulations embody formalization of the desired norms and rules in accordance with the aspirations of the people.

The Islamic Banking Act legislation is a crystallization of political will interacting and competing before it results in an agreement. The desire to legitimize the principles of the Islamic teachings in the context of legal system in Indonesia is an indisputable fact. This effort actually began a long time ago, with both successes and failures. Therefore, based on the data presented above, the researcher assumes that the dynamics of the Islamic Banking Act legislation is not only because of the legal process, but there is also a strong desire and struggle of certain groups. Likewise, those who are not pleased if the principles of Islamic 
law become formalized create resistance or opposition according to their ability. This can be seen from the political decision of the Peace and Prosperity Faction, as the faction initially understands and supports the Islamic Banking bill, but afterwards rejected it and withdrew their support.

Thus, legislation on Act No. 21 of 2008 on Islamic Banking is part of Muslim's efforts to impose their Islamic law in accordance with the existing political system. Since Indonesia is constitutionally not an Islamic State but the State of Pancasila, the State does not allow Muslims to fully realize the Islamic principles of law. Similarly, since Muslims are bound to the national law, which is comprised of the varied aspirations of the society comprising the Western law, Customary law, and Islamic law, the possible way the Muslims may do is to struggle through the politics of law so that Islamic values can be visible in legal products, mainly in the form of legislation.

The formation process of the Act No. 21 in Indonesia cannot be separated from the participation of the community. It can be seen from various civil society organizations, such as Ikatan Cendikiawan Muslim Indonesia/ ICMI (Indonesian Association of Muslim Intellectuals), Majelis Ulama Indonesia (Indonesian Council of Islamic Scholars), and Asosiasi Bank Syariah Indonesia/ASBISINDO (Indonesian Islamic Banking Association), and others that back up the legislative process. This is a logical consequence of a democratic country. As we know, as a political product, law is a reflection of the political will interacting and competing before it ends with an agreement. What is understood as the law in terms of general and abstract rules binding all society is in fact the result of political aspirations and struggle. In practice, anyone or group wishing to include certain values in a legal product should be able to control or convince the legislators that their values are necessary and should be included in the legal product (Mahfud, 2010: 282).
Outside the political forces in political institutions, there are other forces contributing to the legal products produced by the political institutions. Such forces come from various groups and interests guaranteed and that recognize their role and existence according to the provisions of a country following the democratic system. The groups include executives, scientists, social organizations, professional organizations, religious leaders, non-governmental organizations, and others. This Act is not expected to be detailed and technical, but strategic Acts with its primary mission as a tool to force anyone of the State officials to support the rapid growing of a financial system that is appropriate with roots tied to the nation's culture.

\section{The Philosophical Basis of the Legislation}

The promulgation of Act No. 21 of 2008 has been based on the politics of law. The explanation of the Act expresses that, as mandated by Pancasila and the 1945 Constitution of the Republic of Indonesia, the national development goal includes the creation of a just and prosperous society, based on economic democracy by developing an economic system which is based on a fair market. In order to realize this goal, the implementation of national economic development is geared to the economy in favor of the social economics, equitability, independence, reliability, fairness, and competitiveness in the international economy.

The goals set out in article 3 of the Act will be relevant if they are also associated with the explanation of article 2, which notes that the activities which are in accordance with shar ' $a$, and conforms to business activities that do not contain elements of usury (ribā), gambling (maysir), the unclean (gharār), the forbidden (harām), and injustice (zulm) (Khan, 2010). These five components are often viewed as a major disease of the conventional economic system (Siddiqui, 2008). It means that to achieve the national development goal to improve justice, solidarity, and equality of 
people's welfare, all five components should be completely shunned.

From the five above-mentioned components, the most difficult one is to keep away from elements of usury in any transaction, including in banking. On the other hand, discussion about usury itself cannot be separated from the bourgeoning debt because one of the most obvious and frequent kind of usury is riba alnâsi' $a$, practiced by financial institutions and conventional banks (Erol, Kaynak, \& Radi, 1990). Moreover, many have linked ribâ as a direct source of the financial crisis (Ahmed, 2010; Hamidi, 2012). This is also exacerbated by speculations, in addition to increasing debt acquired by interest. Maysir (gambling) includes any actions that are not justified by the Islamic Banking Act. The banks should concentrate on financing small and medium enterprises, which are the forerunners of job creation in Indonesia. To reverse and overcome the challenges caused by debt acquired through interest and also speculation, in support of the operation of the Islamic Banking system, Act No. 21 of 2008 has set some agreement, both in fund raising and financing, such as mudāarabah, musharaka, murābaha, salam, istisha', ijāra, and others. These contracts (' $a q d$ ) are intended not only as a substitute to interest, but also in providing high economic value if viewed from the macroeconomic perspective. Therefore, there are several reasons why rib $\bar{a}$ should be replaced with those contracts (Fadel, 2007).

To address the issue of contracts specified in Act No. 21 of 2008, the authors conducted an interview with Agustianto, Chairman of the Association of Islamic Economist (Ikatan Ahli Ekonomi Islam/IAEI) and Officer of Sharia Economic Society (Masyarakat Ekonomi Syariah/MES). He stated that the contracts as mentioned above are basically more based on the underlying transaction that requires delivery of goods. With the existence of this contract, monetary flow is expected to balance the real sector of national economy. The reason is that if the monetary flow (money) and the flow of goods are balanced, economics will tend to stabilize. This will be able to curb inflation, and avoid the creation of an economic bubble.

Conversely, if money is not balanced with the growing number of goods, it will trigger inflation which often leads to the creation of an economic bubble. Later, when a bubble reaches its tipping point, often a financial crisis is the result.

Therefore, the end goal of the legislation on the Islamic Banking Act should be linked to socio-economic conditions at the national and global levels. It is undeniable that the rise of Islamic banks is motivated to a large extent by existing economic and social conditions. Poverty and inequality of wealth and income, the backwardness of Muslim countries in comparison to most Western countries, as well as remnants of economic and financial colonialism of Western countries provide a rationale for the need for Islamic banks (Chapra, 2006). Even at the present time, Islamic banks and the Islamic financial system are expected to reduce the economic instability and the increasingly systemic world of finance (Čihák, \& Hesse, 2008; Mirakhor \& Krichene, 2009). There is a broader economic and social objective than just changing the rib $\bar{a}$ system itself. Since the first part of the $20^{\text {th }}$ century, many Islamic and conventional economists realize that the interest system cannot optimally realize the economic and social goals (Anto, 2012).

A profit sharing contract, such as mudāraba and musharaka contracts, will require the use of money. With these two agreements, the borrower will use money for business purposes in which profits are shared with the capital or money provider. The murābaha contract, in its ideal practice, requires the goods (Chapra, 2006). Logically, these goods may not be realized if not involving the production aspect. Production itself will involve labors. The availability of goods is a consequence of the production process. In addition, production often leads to entrepreneurship. This does not necessarily 
occur when what is borrowed is in the form of cash. Because, in reality, money can be used for various purposes such as paying off debt and also for investment activities (such as buying and selling of money, etc.), so it must not be a driving force towards these three things: production, entrepreneurship, and employment. In fact, the Qur'ān explains that buying and selling can replace the practice of riba.

Therefore, the major point of the contractagreement in the Islamic Banking Act in Indonesia is how the monetary sector is addressed to, and financial market must be balanced with the real sector of economy producing actually of goods and services (Farooq, 2009). If only relying on the monetary sector alone, there are two possibilities: triggering inflation and eventually creating an economic bubble; and if left unchecked the bubble may burst which would lead to a national financial crisis. Agustianto, Secretary General of the Indonesian Association of Islamic Economist (Ikatan Ahli Ekonomi Islam/IAEI), in one seminar in Jakarta said that a large cause of world's financial crises was based on debt interest. This is because conventional banks require interest to finance their operations (Agustianto, 2008).

Although loans with interest in the conventional banking system that is likely to be able to boost the growth of the economy is now commonly practiced all over the world, al Quran (Surah al-Rum: 39) opposed the assumption by stating "what you give (loans) in the form of riba (usury) so that human wealth will increase, (it) does not increase on Allah's side". That is why the Islamic Banking Act states that in order to ensure legal certainty for all stakeholders and provide assurance to the public in the use of products and services of the Islamic Bank, there are types of business, provisions for the feasibility, disbursement of funds, and ban on the practice of $\operatorname{sharl'}^{\prime} a$ commercial banks and sharì'a business units having been determined. Meanwhile, to convince people doubting the Islamic aspects in the Islamic Banking operations, business activities that do not contradict Islamic principles have been set, including activities that do not contain elements of ribā, maysir, gharār, harām and zulm (Iqbal, 1997).

Philosophically, the presence of the Islamic Banking Act is not simply to maintain sharí'a compliance alone, but its existence is also linked to its performance in realizing the broader goals in economic and social aspects (Anto, 2012). Futhermore, Anto (2012) stated that it cannot be denied that there is an economic and social background of the birth of Islamic banking. Poverty and inequality of wealth and income, the backwardness of Muslim countries compared to Western countries, as well as economic and financial industry domination by the Western countries are some of the main reasons for establishment of Islamic banks. The presence of Islamic banks and the Islamic financial system is expected to reduce the instability of the world economy.There is a broader economic and social goal rather than an escape from riba itself. This economic and social goal is actually rooted in the concept of maqâsid al-shari'a, which is the main purpose for the whole of Islamic law. The main objective of the Islamic shari $\bar{l} a$ is the benefit for human beings and the whole of nature. According to Imam al-Ghazali (10581111), the purpose of sharī' $a$ is to create wellbeing of mankind that lies in the protection of religion (hifz al-din), soul (hifz al-nafs), mind (hifz al-aql), descent (hifz al-nasl), and treasure (hifz al-mâl). Protection against the five basic needs (al-dharuriyyah al-khams) is absolutely necessary to realize the noble and holy life, both in this world and in the hereafter (falâh). Hence, assessment to Islamic banks development must be linked to maqâsisid al-shari'a. Some scholars that were widely noted as the contributors of maqâșid theory include Imam al-Juwaini (10281085), Imam al-Ghazali (1058-1111), Izzuddin ibn Abd Salam (1181-1262), Ibn Al- Qayyim (1292-1350), and al-Syatibi (d. 1388).

Maqāsid al-sharī'a itself is the objective and secret set by the shari'a (law maker or the God) of any law of the shari'a laws (Ali, 
2007). Maqāsid al-sharī'a is an effort to realize the benefit for people in the world and in the hereafter by bringing the usefulness and resisting damage. The core of the maqāsid alsharì'a is al-mașlaha in a broader sense. The benefit becoming the objectives of Islamic law if viewed from its impact on individuals and groups are divided into three: (1) the primary benefit (darūriyya), (2) the secondary benefit (häjiyya), and (3) the tertiary benefit (tahsiniyya). Next, benefits as seen from its relationship with the individual and the group is divided into two. The first is the universal benefit (kuliyya), which goes back to the whole people or a large group with kindness and expediency; and the second is special benefit ( $k h \bar{a} s \underline{s} a$ ) referred to the benefit for an individual or a few individuals (Asmani, 2015).

The performance evaluation of Islamic banks from a maqâsid al-shari' a perspective requires an assessment of the two aspects at once, namely shari 'acompliance and the ability to understand the needs of the people against the five things listed above. Indeed, these two aspects are interrelated in realizing maqashid al-sharì'a. Shari 'a compliance is a necessary condition, while the ability to understand the needs of the people is a sufficient condition for achieving the maqāsid al-sharī'a. In other words, Islamic banks must meet all terms and conditions of figh al mu' 'amala first, and then be substantially able to meet the needs of the people. The benefits for the people cannot be achieved by ignoring the strict adherence to the provisions of fiqh mu'âmala; otherwise, textual adherence to fiqh mu'āmala by ignoring mașlaha to people can eliminate the substance of sharī'a itself. Hence, basing the Banking Act on the aspects of mașlaha, both kuliyya and khāșsa becomes important.

\section{Concluding Remarks}

This study provides two main conclusions. First, the Islamic Banking Act in Indonesia has a strong relationship with the evolving political conditions at that time, which is democratic in nature. The establishment of the Islamic Banking Act is a crystallization of the political aspirations interacting and competing with one another, which subsequently results in an agreement. The national legal system provides opportunities for all legal orders that develop and are applicable in the community, including Act No. 21 of 2008 on Islamic banking, to become the national law. Islamic laws are recognized as applicable laws in many communities and are also likely to become national laws so far as they can express the three principles of fairness, certainty, and expediency after going through transparent approval processes and procedures.

Second, based on the author's research, legislation on the Islamic Banking Act, in addition to the legal aspect, is based largely on the philosophical aspects leading to the mașlaha aspects in the Islamic law. The embodiment of the mașlaha aspect is linked to efforts to realize the goals or objectives of the State. The mașlaha embodiment, at least, includes hifz al-māl (economic prosperity) and hifz al-nafs (happiness of Indonesian society in general), in which the Islamic Banking Act aims at supporting the implementation of national development in order to improve social justice, solidarity, and equitable welfare. In this regard, Islamic Banking is consistent with the Shar '̀ a principles comprehensively ( $k a \overline{f f} a$ ) and consistently (istiqāma).

\section{References}

Afsaruddin, A. (2011). Introduction. In Islam, the State, and Political Authority (pp. 1-5). Palgrave Macmillan US.

Agustianto. (2008). Islamic Economics Solutions to Global Financial Crisis. Seminar Paper at the State University of Jakarta (UNJ), Jakarta.

Ahmed, A. (2010). Global Financial Crisis: an Islamic Finance Perspective. International Journal of Islamic and Middle Eastern Finance and Management, 3(4), 306-320. 
Ahmed, H. (2006). Islamic law, adaptability and Financial Development. Islamic Economic Studies, 13(2), 79-101.

Ali, F., \& Effendy, B. (1986). Merambah Jalan Baru Islam: Rekontruksi Pemikiran Islam Indonesia Masa Orde Baru. Mizan.

Ali, M. A. (2007). Al-Maqashid al-Sharī’a wa al-Fiqhi Atsaruha fi al-Islamy. Cairo: Dar alHadith.

Al-Syatibi. (1341 H). Al-Muwafaqat fi Usul al-Ahkam (volume II). Dar al-Fikr.

Anto, M. B. H.(2012). Maqashid Syariah: Analisis Kelembagaan Perbankan Syariah. Journal of Science and Culture Ulumul Qur'an, 02 (XXI).

Asmani, J. M. (2015). Mengembangkan Fiqh Sosial KH. M. A. Sahal Mahfudh; Elaborasi Lima Ciri Utama. Jakarta: PT Elex Media Komputindo

Black, A. (2011). History of Islamic Political Thought: From the Prophet to the Present. Edinburgh: University Press.

Chapra, M. U. (2006). Islamic Perspectives on Wealth Creation. Edinburgh: Edinburgh University Press.

Čihák, M., \& Hesse, H. (2008). Islamic Banks and Financial Stability: An Empirical Analysis. IMF Working Papers, 1-29.

Dogarawa, A. B. (2012). Global Financial Crisis and The Search for New Financial Architecture: Can Islamic Finance Provide Alternative. Journal of Islamic Economics, Banking and Finance, 8(4), 33-48

Dusuki, A. W., \& Abdullah, N. I. (2007). Maqasid al-shari'ah, Maslahah and Corporate Social Responsibility. The American Journal of Islamic Social Sciences (AJISS), 24(1), 25-45.
Dusuki, A. W., \& Bouheraoua, S. (2011). The Framework of Maqasid al-Shari'ah and its Implication for Islamic Finance. Islam and Civilisational Renewal, 2(2), 316.

Erol, C., Kaynak, E., \& Radi, E. B. (1990). Conventional and Islamic banks: Patronage Behaviour of Jordanian Customers. International Journal of Bank Marketing, 8(4), 25-35.

Fadel, M. H. (2007). Riba, Efficiency, and Prudential Regulation: Preliminary Thoughts. Wis. Int'1 LJ, 25, 655

Farooq, M. O. (2009). Global Financial Crisis and the Link Between the Monetary and Real Sector: Moving Beyond the Asset-Backed Islamic Finance. In Proceeding of the 20th Annual Islamic Banking Seminar.

Feener, R. M. (2007). Muslim Legal Thought in Modern Indonesia. Cambridge University Press.

Ghoul, W. A. (2011). The Dilemma Facing Islamic Finance and Lessons Learned from the Global Financial Crisis. Journal of Islamic Economics, Banking and Finance, 7(1), 57-76.

Griffith-Jones, R. (2013). Islam and English Law: Rights, Responsibilities and the Place of Shari'a. Cambridge: Cambridge University Press.

Hadiz, V. R. (2011). Indonesian Political Islam: Capitalist Development and the Legacies of the Cold War. Journal of Current Southeast Asian Affairs, 30(1), 3-38.

Hamidi, M. L. (2012). Krisis Manalagi yang Engkau Dustakan. Jakarta: Republika.

Hartono, S. (1991). Politik Hukum Menuju Satu Sistem Hukum Nasional. Bandung: Penerbit Alumni.

Iqbal, Z. (1997). Islamic Financial Systems. Finance and Development, 34, 42-45. 
Jaspan, M. A. (1965). In Quest of New Law: The Perplexity of Legal Syncretism in Indonesia. Comparative Studies in Society and History, 7(3), 252-266.

Khallaf., A., W. (1977). Ilm Usul al-Fiqh. Cairo: Dar al-Qalam.

Khan, F. (2010). How 'Islamic is Islamic Banking? Journal of Economic Behavior \& Organization, 76(3), 805-820.

Khan, M. M. (Ed.). (2006). Islamic Democratic Discourse: Theory, Debates, and Philosophical Perspectives. Lexington Books.

Lindsey, T. (2008). Syariah Law in Indonesia: Revival, Reform or Transplantation? In Examining Practice, Interrogating Theory: Comparative legal studies in Asia (pp. 195222). Brill.

Mahfud, M., D. (2010). Politik Hukum di Indonesia. Jakarta: Rajawali Pers.

Mansour, W. (2014). Maqasid Foundations of Market Economics By Seif Ibrahim Tag elDin. Journal of Islamic Studies, 25(3), 400-402.

Mirakhor, A., \& Krichene, N. (2009). The recent Crisis: Lessons for Islamic Finance. MPRA Paper No. 56022. Online http://mpra.ub.unimuenchen.de/56022.

Opwis, F. (2005). Maslaha in Contemporary Islamic Legal Theory. Islamic Law and Society, 12(2), 182-223.

Ramage, D. E. (1997). Politics in Indonesia: democracy, Islam, and the Ideology of Tolerance. Psychology Press.

Rosadi, O., \& Desmon, A. (2012). Studi Politik Hukum: Suatu Optik Ilmu Hukum. Yogyakarta: Thafa Media.

Salam, M. (2016). Al-Dawlah wa al-Da 'wah al-Islāmīyah fī ‘Ahd al-Nizāàm al-Jadīd: Studia
Islamika, 23(1), 143-174.

Shah, N. A. (2006). Women's Human Rights in the Koran: An Interpretive Approach. Human Rights Quarterly, 868-903.

Siddiqui, A. (2008). Financial Contracts, Risk and Performance of Islamic Banking. Managerial Finance, 34(10), 680-694.

Subhi, M. (1961). The Philosophy of Islamic Jurisprudence Industry, translated by Farhat J. Ziadeh, Leiden: Brill E.J.

Suny, I. (2017). Hukum Islam dalam Hukum Nasional. Jurnal Hukum \& Pembangunan, 17(4), 351-357.

Tanya, L. B.(2011). Politik Hukum Agenda Kepentingan Bersama. Yogyakarta: Genta Publishing.

Thaba, A. A., \& Gaffar, A. (1994). Islam dan Negara Dalam Politik Orde Baru (19661994) Doctoral dissertation. Yogyakarta: Universitas Gadjah Mada.

Thalib, S. (1980). Receptie a Contrario (hubungan antara hukum adat dan hukum Islam). Jakarta: Academika.

Tobroni, F. (2009). Keberhasilan Hukum Islam Menerjang Belenggu Kolonial dan Menjaga Keutuhan Nasional. UNISIA, 32(72). 